\title{
Methodology to compare costs of sanitation options for low-income peri-urban areas in Lusaka, Zambia
}

\author{
E von Münch ${ }^{1 *}$ and KMK Mayumbelo ${ }^{2}$ \\ 1 Urban Water and Sanitation Department, UNESCO-IHE Institute for Water Education, Westvest 7, 2611 AX Delft, the Netherlands \\ ${ }^{2}$ Peri-urban Department, Lusaka Water and Sewerage Company, PO Box 50198 RW, Lusaka, Zambia
}

\begin{abstract}
Urban slums and low-income peri-urban areas in developing countries are characterised by a lack of infrastructure. The absence of sustainable sanitation systems is one of the causes that can lead to a high level of water-borne diseases in these areas, especially during the rainy season. This paper presents a methodology for cost comparisons of sanitation system options with a focus on excreta management (a sanitation system consists of the household toilets, collection and transport of excreta, treatment and storage, and transport of sanitised excreta to reuse sites). Greywater collection and treatment are excluded from the analysis for simplicity reasons.

We used three low-income peri-urban areas in Lusaka, Zambia, to demonstrate our proposed methodology. The population density in the three peri-urban areas ranges from 104 to 244 people/ha. Unlined pit latrines are the most common form of excreta management, even though drilled boreholes and shallow wells are used as sources for drinking water in the same areas.

Based on four selection criteria (no use of water for transporting the waste, low costs, waste sanitisation, and no contribution to groundwater pollution from stored excreta), we have short-listed two options which meet most or all of the criteria: A conventional low-cost option (Option 5: VIP latrines with downstream processing) and an ecological sanitation option (Option 6: urine-diversion dehydrating (UDD) toilets with downstream processing). The concept designs for both options are based on the entire peri-urban population in Lusaka of approximately $1.23 \mathrm{~m}$. people, and on the assumption that 12 residents who live on the same plot (or 'compound') would share one toilet.

The paper details the assumptions used to create a set of default model input parameters which are used in the cost equations to calculate capital costs, annual operating costs and net present values (NVP). Based on this basic financial analysis, we calculated the following indicative costs: capital costs of $31 € /$ cap and $39 € /$ cap for Option 5 and Option 6, respectively. Annual operating costs per capita were estimated to be $2.3 € / \mathrm{a} \cdot \mathrm{cap}$ and $2.1 € / \mathrm{a} \cdot \mathrm{cap}$ ) for Option 5 and Option 6 , respectively.

The NPV for Option 6 is about 14\% higher than for Option 5 but the difference is not significant, given the accuracy of the cost estimate (about $\pm 25 \%$ ). Overall, this paper shows that the two options are difficult to differentiate based on cost alone. The financial model allows examination of the relative contributions of the different components to the overall cost of the sanitation system. For example, the costs of urine storage and transport are significant contributors to the capital and operating costs of the Ecosan option, and ways to reduce these costs should be investigated.
\end{abstract}

Keywords: NPV, millennium development goals, groundwater, ecological sanitation, Ecosan, VIP latrine, UDD toilet, financial model, reuse, excreta

\section{Introduction}

\section{Background}

As a consequence of the rapid urbanisation process in many developing countries, communities of very poor people are now living in the inner city or periphery of those rapidly growing cities. These urban slums and unplanned low-income peri-urban areas are characterised by a lack of infrastructure.

Provision of safe water and sustainable sanitation for the urban poor is required as one of the factors to ensure public health, but is challenging for reasons such as insecure tenure, lack of political will, financing, cost recovery and choice of technical options. If municipalities and commercial utilities want to provide low-cost sanitation to peri-urban areas, which of the

* To whom all correspondence should be addressed.

용 +31 15 2151886; fax: +31 15 2122921;

e-mail: e.vonmunch@unesco-ihe.org

Received 26 February 2007; accepted in revised form 29 June 2007. following technologies should they select for excreta management?

- Conventional water-borne sanitation with sewers or conventional on-site sanitation (pit latrines, septic tanks)?

- Ecological sanitation (e.g. urine-diversion dehydrating toilets)?

We propose a methodology for comparing costs of sanitation options, consisting of the following steps:

- Analyse existing sanitation situation (we used three periurban areas in Lusaka as an example)

- Define possible sanitation options and selection criteria

- Short-list a small number of options (two in our case) based on the selection criteria

- Prepare concept designs for the short-listed options

- Prepare cost estimates based on the concept designs, using basic cost equations proposed in this paper

- Compare results based on overall cost (net present value) and other sustainability factors (other sustainability factors are only touched upon in this paper). 


\begin{tabular}{|l|c|c|c|}
\hline \multicolumn{4}{|c|}{$\begin{array}{l}\text { TABLE 1 } \\
\text { Key characteristics of Bauleni, Chawama and John Laing peri-urban areas (GKW (2005) } \\
\text { and own data marked with *) }\end{array}$} \\
\hline Characteristic & Bauleni & Chawama & John Laing \\
\hline Approximate population & 26000 & 68000 & 82000 \\
\hline Number of plots & 2790 & 7608 & 9638 \\
\hline Number of households & 6166 & 8179 & 15806 \\
\hline Typical number of households per plot * & 2 & 3 & 4 \\
\hline Approx. population density in people per hectare * & 104 & 244 & 160 \\
\hline Expenditure on water as \% of household income * & \multicolumn{3}{|c|}{0.7 to 5\% (for all three areas) } \\
\hline $\begin{array}{l}\text { Legal status } \\
\text { Recognised by municipality }\end{array}$ & $\begin{array}{c}\text { In process of } \\
\text { recognition }\end{array}$ \\
\hline $\begin{array}{l}\text { Frequency of outbreaks of water-borne diseases } \\
\text { (dysentery or other diarrhoea) * }\end{array}$ & \multicolumn{3}{|c|}{ Ender (for all three areas) } \\
\hline
\end{tabular}

In this paper, we focused on excreta management options and did not include greywater management - for reasons of simplicity and because in the peri-urban areas of Lusaka, excreta management is thought to have more urgency compared to greywater management with respect to public health protection.

\section{Description of three peri-urban areas in Lusaka}

Lusaka is the capital of Zambia in Southern Africa with a population of approximately $2 \mathrm{~m}$. people in 2005 (annual growth rate of $3.5 \% / \mathrm{a}(\mathrm{CSO}, 2003))$; of which approximately $1.23 \mathrm{~m}$. people live in low-income unplanned peri-urban areas, a majority of which are slum-like in character (GKW, 2005). The water supply service in the peri-urban areas of Lusaka is rudimentary, and sanitation service provision by Lusaka City Council to those areas is almost non-existent.

We selected three typical peri-urban areas (Bauleni, Chawama and John Laing) to collect baseline information for the development of subsequent options. The fieldwork was carried out in Lusaka from November to December 2005 and is described in detail in Mayumbelo (2006). Field observations and informal discussions were used to investigate the current water and sanitation practices, state of the infrastructure and residents' health with respect to water-borne diseases.

Table 1 summarises important characteristics of the three study areas, and Table 2 summarises the main research findings with regards to sanitation and water aspects for the three areas.

Sanitation provision in the peri-urban areas is generally left to the initiative of the residents who mostly use unlined pit latrines that they dig within their plot boundaries. The pits are covered with soil once they are full. The liquid fraction of the excreta percolates into the ground and ultimately reaches the groundwater. The groundwater table ranges from deep (approx. $30 \mathrm{~m}$ ) to shallow (approx. $1 \mathrm{~m}$ ). Karst features of the geological formations underlying Lusaka make it complicated to predict in which direction and at what velocity groundwater will flow, and makes it difficult to dig new pits (see Fig. 1).

Many residents in Chawama and John Laing use hand-dug shallow wells as a source of drinking water (see Fig. 2). This practice can be detrimental to their health since the groundwater quality in Lusaka fluctuates seasonally: it tends to deteriorate during the rainy season when pollution and recharge occurs due to pit latrines and the presence of preferential fast-flow mechanisms in the karst rock formations (Nkuwa, 2002). This problem is one of the causes of recurrent outbreaks of waterborne diseases in Lusaka's peri-urban areas (Mayumbelo, 2006). It is in fact a general problem for many areas in sub-Saharan

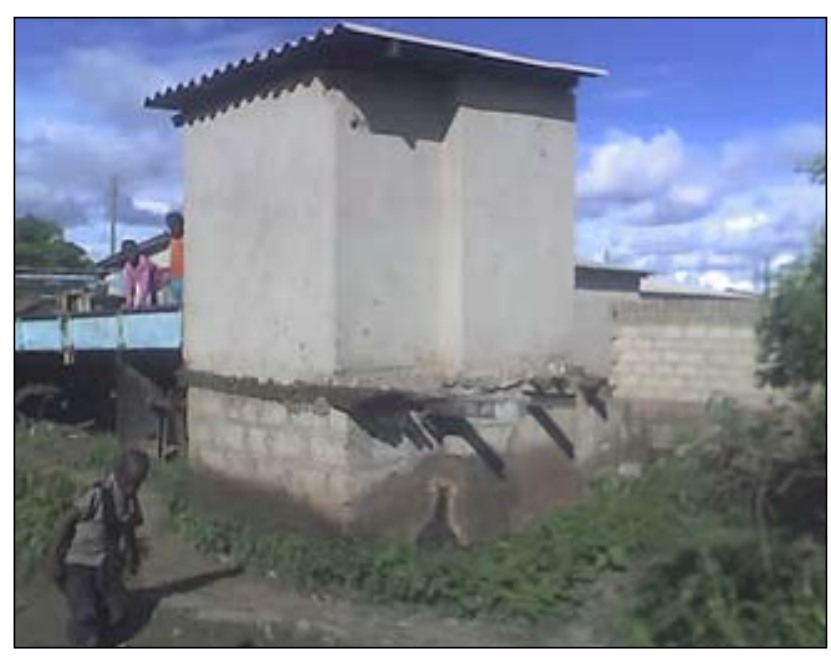

Figure 1

Raised pit latrine in the peri-urban area John Laing (rocky ground makes it difficult to dig pits)

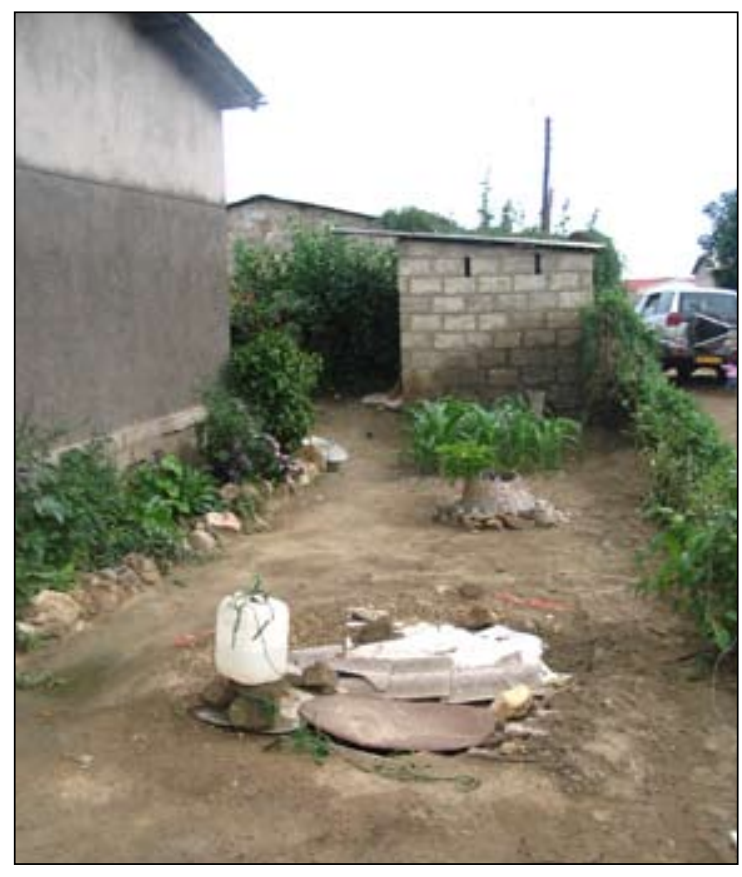

Figure 2

Hand-dug shallow well near a pit latrine (background) in the peri-urban area John Laing 


\begin{tabular}{|c|c|c|c|}
\hline \multicolumn{4}{|c|}{$\begin{array}{c}\text { TABLE } 2 \\
\text { Summary of sanitation and water aspects for three peri-urban areas in Lusaka, Zambia }\end{array}$} \\
\hline Aspect & Bauleni & Chawama & John Laing \\
\hline $\begin{array}{l}\text { Main sanitation practice } \\
\text { - types of toilets }\end{array}$ & $\begin{array}{l}\text { Unlined pit latrine (see } \\
\text { Fig. 1) }\end{array}$ & $\begin{array}{ll}\text { - } & \text { Unlined pit latrine } \\
\text { - } & \text { Water-flush toilet and septic tank } \\
\text { with soak-away } \\
\text { - Use of plastic bags for defecation } \\
\text { ('flying toilets') }\end{array}$ & $\begin{array}{l}\text { - Unlined pit latrine } \\
\text { Use of plastic bags for } \\
\text { defecation }\end{array}$ \\
\hline Greywater disposal method & \multicolumn{3}{|c|}{$\begin{array}{ll}\text { - } & \text { Disposed in road drains } \\
\text { - } & \text { Soaked around point of discharge } \\
\end{array}$} \\
\hline Ownership of toilet & \multicolumn{3}{|c|}{$\begin{array}{l}\text { Usage of toilet is commonly shared by all tenants on the plot (average of } 12 \text { people) but officially the } \\
\text { landlord owns the toilet structure }\end{array}$} \\
\hline $\begin{array}{l}\text { Problems identified by } \\
\text { users with current practice }\end{array}$ & $\begin{array}{ll} & \text { Odour } \\
\text { - } & \text { Breeding ground for } \\
& \text { flies and other vectors }\end{array}$ & $\begin{array}{ll} & \text { Frequent collapsing of pits } \\
\text { - } & \text { Rocky ground makes it difficult to } \\
\text { dig new pits }\end{array}$ & $\begin{array}{l}\text { - Pollution of shallow } \\
\text { wells } \\
\text { - Shallow water table }\end{array}$ \\
\hline $\begin{array}{l}\text { Status of sanitation infra- } \\
\text { structure }\end{array}$ & \multicolumn{2}{|c|}{ Satisfactory to poor } & Poor \\
\hline $\begin{array}{l}\text { Residents without their } \\
\text { own toilets }^{\mathrm{a}}\end{array}$ & $5 \%$ & $3 \%$ & $21 \%$ \\
\hline $\begin{array}{l}\text { Main drinking water } \\
\text { sources }\end{array}$ & $\begin{array}{l}\text { Drilled deep boreholes } \\
\text { within Bauleni }\end{array}$ & $\begin{array}{l}\text { Drilled deep boreholes within Cha- } \\
\text { wama, and supply from Lusaka Water } \\
\text { and Sewerage Company (LSWC) central } \\
\text { network }\end{array}$ & $\begin{array}{l}\text { One drilled deep borehole } \\
\text { and supply from a small } \\
\text { extension of LWSC central } \\
\text { network }\end{array}$ \\
\hline $\begin{array}{l}\text { Alternative drinking water } \\
\text { sources }\end{array}$ & None & \multicolumn{2}{|c|}{$\begin{array}{l}\text { Shallow hand-dug wells (see Fig. 2) } \\
\end{array}$} \\
\hline $\begin{array}{l}\text { Financing of sanitation } \\
\text { service }\end{array}$ & \multicolumn{3}{|c|}{$\begin{array}{l}\text { Constructed by tenants or landlords, operated and maintained by tenants; costs vary as some } \\
\text { residents may abandon a full toilet while others attempt to have it emptied (manually or by vacuum } \\
\text { tanker) }\end{array}$} \\
\hline
\end{tabular}

Figure 3

Sanitation system components which are included in the cost estimate in this paper (components indicated with dashed arrows and the greywater management system are not included in the cost estimate)

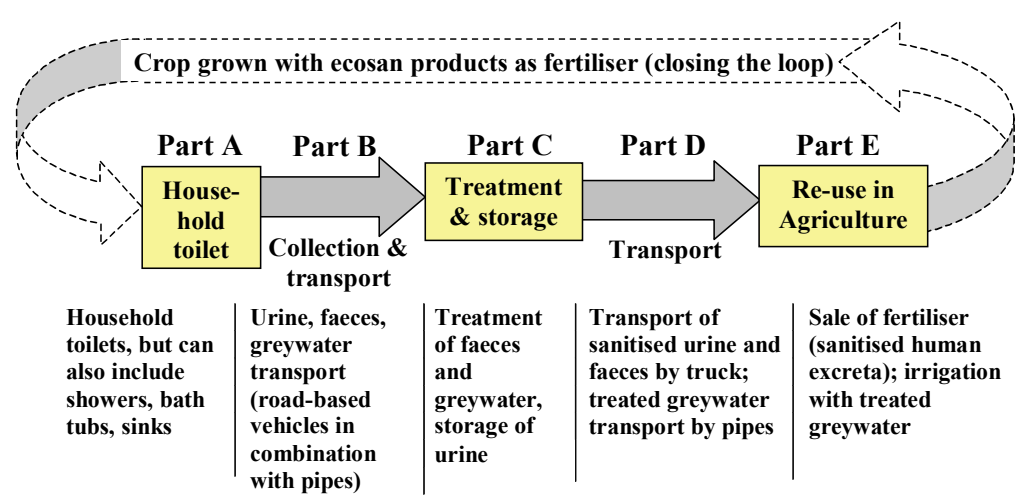

Africa with shallow urban groundwater, where the increase in diarrhoea incidents in the rainy season can be attributed to pit latrines in peri-urban areas (Lerner, 2004). Diarrhoeal diseases can be caused by many different factors and disease transmission routes; inadequate excreta management is an important factor and is the focus of this paper.

\section{Sanitation system options for peri-urban areas in Lusaka}

\section{Options short-listing procedure}

We advocate applying a 'systems approach' to sanitation and as such, 5 major parts of the sanitation system ought to be distinguished (Fig. 3):

- Part A: Household toilets

- Part B: Collection and transport of excreta from households to treatment site
- Part C: Treatment and storage of excreta at (semi-) centralised location

- Part D: Transport of sanitised excreta from treatment site to agricultural fields

- Part E: Reuse of excreta in agriculture (sale of fertiliser).

For rural areas, the distances between Part A and Part E are very short, and they may therefore have negligible impact on the overall cost. But for urban situations, Part B to D may have significant cost implications. Another consideration is that whilst Part A can be designed for individual households, Parts B to E should be designed to cover many households to achieve economies of scale.

We considered six sanitation options, which are schematically presented in Fig. 4. Each of the six options is meant to cover the entire system (Part A to E). Options 1 to 5 are wellknown conventional sanitation options, whereas Option 6 is the still relatively unknown ecological sanitation (Ecosan) 


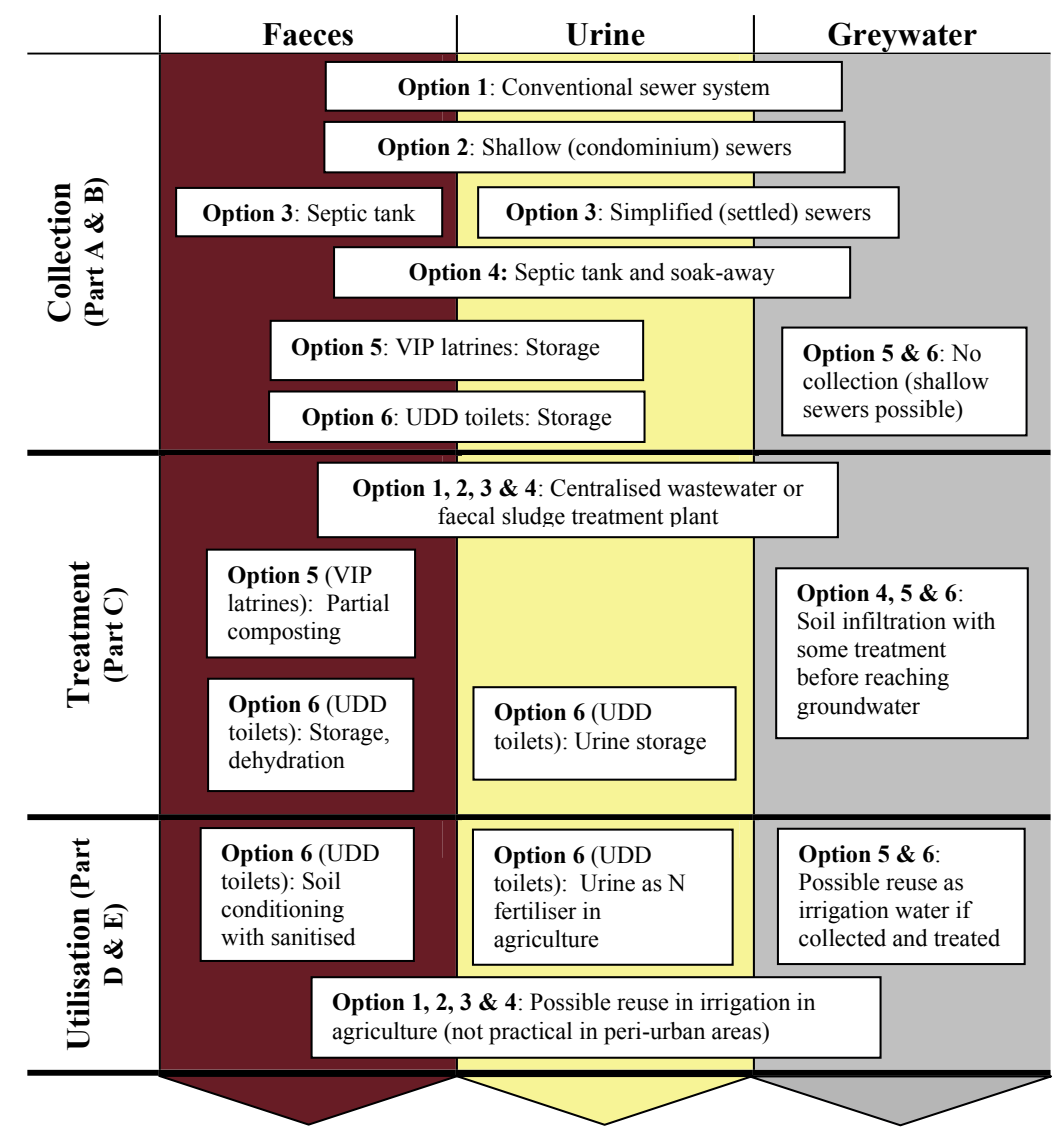

Figure 4

Sanitation options for periurban areas of Lusaka. Options 1-4 include waterflush toilets, whereas Options 5 and 6 use waterless toilets (VIP $=$ ventilated improved pit). All options include downstream processing of the excreta. Greywater management is not included in cost estimate. option (Drangert, 1998), which is described in more detail below.

Ecosan is a new paradigm in sanitation which aims to enable safe reuse of sanitised excreta and greywater (Winblad and Simpson-Hébert, 2004) and be sustainable in all aspects. The nitrogen, phosphorus and organic matter in sanitised urine and faeces can be used in agriculture as a fertiliser and soil conditioner, respectively. This aspect is particularly important for poor people living in areas of nutrient-depleted soils in subSaharan Africa who cannot afford to purchase artificial inorganic fertiliser. In general, Ecosan options do not rely on the soil for storage of excreta and infiltration of urine, and therefore significantly reduce the danger of leaching of nitrate and pathogens into groundwater (as may occur from the pits of pit latrines). A further advantage is that Ecosan technologies can typically be implemented at much lower costs than conventional waterborne sewers (UNEP, 2004).

Ecosan interventions also have the potential to contribute to a whole range of Millennium Development Goals (MillenniumProject (2005), Rosemarin (2003), Von Münch et al. (2006)), e.g. those related to basic sanitation provision, improvement of lives of slum dwellers, reduction of hunger, extreme poverty and child mortality. Higher agricultural yields of fields fertilised with Ecosan products can lead to a lower incidence of malnutrition and hence lower levels of morbidity.

The urine-diversion dehydrating (UDD) toilet is one of the numerous possible toilet types that can be used within an Ecosan approach. It separates the urine and faeces in the toilet, and the two substances are stored and treated separately from each other (GTZ, 2007). The faeces are air-dried in a ventilated single vault or double vault configuration (the second vault is used once the first vault is full), with the aim to achieve pathogen kill and volume reduction. The single vault system is used for the cost comparison in this paper because of its lower investment costs. Its main disadvantage is that some of the faeces are still fresh when the vault is being emptied; the associated health risk can be managed for example by ongoing hygiene education programmes for the workers who empty the toilet vault after one year (Moilwa and Wilkinson, 2006).

UDD toilets do not use water for flushing, which is important for areas with unreliable water supply, such as the peri-urban areas of Lusaka. UDD toilets are also quite simple to operate (compared to some composting toilet types), resilient to floods, and the toilets can be located on any level inside the house. The dried faecal matter from a UDD toilet is less offensive and odorous than faecal sludge from pit latrines because faeces are not combined with urine or water. For these reasons, the UDD toilet is used to represent Part A of the Ecosan option (Option 6) in this cost comparison.

In order to narrow down the available options for the purposes of a cost comparison, we can consider sustainability criteria. Based on the approach presented by Kvarnström and Af Petersens (2004), we applied the following 4 selection criteria for the short-listing:

- Should not require water for transporting waste (poor water supply levels in peri-urban areas)

- Have low capital, operation and maintenance costs to be financially sustainable

- Should sanitise the waste to destroy pathogens to protect public health

- Should not contribute to groundwater pollution via leaching of nitrate and pathogens from stored excreta, since shallow wells are being used as a drinking water source (it is unlikely that this practice will be abandoned in the foreseeable future in Lusaka and replaced by piped (treated) water from other sources, mainly due to lack of capital). 
TABLE 3

Summary of concept design for short-listed options (for Lusaka's peri-urban population of 1.23 m. people)

\begin{tabular}{|c|c|c|c|c|}
\hline & \multicolumn{2}{|c|}{ Items which have an impact on capital costs } & \multicolumn{2}{|c|}{ Items which have an impact on operating costs } \\
\hline & $\begin{array}{l}\text { Option } 5 \\
\text { (VIP toil. } \\
+ \text { processing) }\end{array}$ & $\begin{array}{c}\text { Option } 6 \\
\text { (UDD toilets + processing) }\end{array}$ & $\begin{array}{c}\text { Option } 5 \\
\text { (VIP toilets + processing) }\end{array}$ & $\begin{array}{c}\text { Option } 6 \\
\text { (UDD toilets + processing) }\end{array}$ \\
\hline $\begin{array}{l}\text { Part A: } \\
\text { Household } \\
\text { toilets }\end{array}$ & $\begin{array}{l}\text { VIP toilets (102 } 400 \\
\text { toilets), first } 1.2 \mathrm{~m} \text { of } \\
\text { pit is lined }\end{array}$ & $\begin{array}{l}\text { Single vault UDD toilets ( } 102400 \\
\text { toilets), designed to fill vault in one year; } \\
2 \times 200 \ell \text { plastic barrels per toilet for } \\
\text { urine storage }\end{array}$ & None & $\begin{array}{l}\text { None (sand, soil or ash as addi- } \\
\text { tive to faeces chamber is avail- } \\
\text { able at no or negligible cost) }\end{array}$ \\
\hline $\begin{array}{l}\text { Part B: } \\
\text { Collection and } \\
\text { transport of } \\
\text { excreta }\end{array}$ & $\begin{array}{l}16 \text { vacuum tankers } \\
\text { to transport the fae- } \\
\text { cal sludge }\end{array}$ & $\begin{array}{l}\text { Transport vehicles: } \\
\text { - } 2 \text { open trucks with skips to transport } \\
\text { dried faecal matter } \\
\text { - } 28 \text { open trucks to transport urine bar- } \\
\text { rels (pick up once per week; } 115 \ell \text { per } \\
\text { plot per week, from } 12 \text { people) }{ }^{\text {b }} \\
\end{array}$ & $\begin{array}{l}\text { Faecal sludge pumping from } \\
\text { the pit once it is full, and } \\
\text { transport (includes fuel, } \\
\text { maintenance on trucks, sal- } \\
\text { ary overheads) }\end{array}$ & $\begin{array}{l}\text { Emptying of vaults (cost similar } \\
\text { to garbage collection services). } \\
\text { Transport cost for faecal matter } \\
\text { and urine barrels; includes fuel, } \\
\text { maintenance on trucks, salary, } \\
\text { overheads. }\end{array}$ \\
\hline $\begin{array}{l}\text { Part C: } \\
\text { Treatment } \\
\text { and storage of } \\
\text { excreta }\end{array}$ & $\begin{array}{l}\text { One faecal sludge } \\
\text { treatment plant } \\
\text { consisting of settling } \\
\text { tanks, drying beds, } \\
\text { co-composting with } \\
\text { organic solid waste } \\
\text { and waste stabilisa- } \\
\text { tion ponds for faecal } \\
\text { sludge liquor } \\
\end{array}$ & $\begin{array}{l}\text { No treatment required, only storage }{ }^{\mathrm{d}} \text { : } \\
\text { - Dried faecal matter stored for } 6 \\
\text { months on } 2 \mathrm{~m} \text { high piles on concrete } \\
\text { slabs, covered with tarpaulin sheets } \\
\text { during rainy season to avoid leaching } \\
\text { of the nutrients } \\
\text { - Plastic urine storage tanks for } 2 \text { weeks } \\
\text { storage to allow collection for reuse } \\
\text { (415 plastic tanks of } 57 \mathrm{~m}^{3} \text { each) }\end{array}$ & $\begin{array}{l}\text { Staff labour for operating } \\
\text { the faecal sludge treatment } \\
\text { plant (use standard figure for } \\
\text { cost of treatment by Lusaka } \\
\text { Water and Sewage Company } \\
\text { based on septic tank sludge, } \\
\text { in } € / \mathrm{m}^{3} \text { ). }\end{array}$ & $\begin{array}{l}\text { Assume } 5 \text { workers managing } \\
\text { the incoming and outgoing } \\
\text { flows of material. }\end{array}$ \\
\hline $\begin{array}{l}\text { Part D: Trans- } \\
\text { port of san. } \\
\text { excreta }\end{array}$ & \multicolumn{4}{|c|}{$\begin{array}{l}\text { Open trucks could be used but they are not included in cost estimate because we assume that the farmers who buy the fertiliser } \\
\text { will organise the transport. Farmers will also need further urine storage of some form because nitrogen fertilisation is not car- } \\
\text { ried out all year round; storage in the ground (soil) may be an option in some cases. }\end{array}$} \\
\hline $\begin{array}{l}\text { Part E: Reuse } \\
\text { in agriculture }\end{array}$ & No capital cost $i$ & tems (buying of land is not included) & $\begin{array}{l}\text { Sale of treated sludge } \\
\text { (compost) }\end{array}$ & $\begin{array}{l}\text { Sale of Ecosan products } \\
\text { (sanitised faeces and urine) }\end{array}$ \\
\hline
\end{tabular}

\section{Notes for Table 3:}

a First $1.2 \mathrm{~m}$ of pit is lined with bricks and mortar to prevent pit from collapsing (remainder of the pit is porous to allow liquid to infiltrate into soil).

${ }_{b} \quad$ Number of trucks is based on 40 urine barrels per load, 2 h return trip, 12 working hours per day to transport the mass flows of Part B (see Table 7).

For faecal sludge pumping to work, water has to be jetted into the pit to liquefy the faecal sludge sufficiently.

${ }^{d}$ The secondary treatment of faeces (further storage and drying) would cause further pathogen die-off and

therefore reduce the risk of disease transmission.

Options 1 to 4 (shown in Fig. 4) are discarded because they do not meet the first two selection criteria. Especially Option 1 (conventional sewer system) is comparatively expensive and requires a high level of institutional capacity and skilled work-force.

Of the six options considered, the only option that satisfies all the selection criteria is Option 6 (UDD toilets with downstream processing). Option 5 (VIP latrines with downstream processing) does not meet the last selection criterion: with the difficult ground conditions in Lusaka, pit latrines can contribute to groundwater pollution via leaching of nitrate and pathogens (pits are designed to allow infiltration of liquid; a 'lined pit latrine' only has lining at the top part of the hole to stabilise it).

In general, pit latrines are not appropriate when the groundwater table is shallow, the population density is high and groundwater is used for drinking water, the ground is underlain by pervious rock (e.g. karst geology) or rock that is difficult to excavate, the area has a potential for flooding, or the population has no means to either dig new pits or to safely empty full pits and treat the faecal sludge.

Even though Option 5 does not meet the fourth selection criterion (related to potential impact on groundwater), it is nevertheless included in the cost analysis in order to test the common perception that an Ecosan option (Option 6) is more expensive than a conventional low-cost on-site sanitation option (Option 5). It should be pointed out that groundwater contamination can also be caused by other factors, e.g. greywater infiltration (Carden et al., 2007), agricultural runoff, industrial pollution, or when residents use contaminated buckets to draw water from shallow wells. Hence, even with Option 6 implemented, groundwater pollution could still continue to be a problem in Lusaka if the other causes for groundwater pollution are not addressed as well.

\section{Concept designs of two short-listed options}

The concept designs of the two short-listed options are summarised in Table 3. They are based on the entire peri-urban population in Lusaka of $1.23 \mathrm{~m}$. people, because certain components (e.g. treatment plant, vacuum tankers or trucks) are more economical on a larger scale. One toilet would be built per plot, and each toilet would be shared by three four-member households.

If the project was implemented, one would first begin with smaller pilot schemes to test the design. For the purposes of the cost estimates presented here, a full-scale implementation is assumed to demonstrate the approach for cost estimating (sanitation pilot projects typically have a higher per capita cost than full-scale projects).

As shown in Table 3, our concept design for Option 6 includes a centralised storage facility for the dried faecal matter and urine. Other treatment options (on plot or centralised) for the faecal matter could include:

- Co-composting with organic waste (as assumed for Option 5)

- Burial of the faecal matter in the ground provided the groundwater table is very deep and precipitation is not that heavy and frequent (Guness et al., 2006) 


\begin{tabular}{|c|c|c|c|c|}
\hline $\begin{array}{r}\text { TABLE } \\
\text { Capital cost of one toilet (for Part A); includes material an } \\
\text { (pit for Option 5, vault for Option 6); assuming cross-secti } \\
\text { depth (freeboard) of } 0.6 \mathrm{~m} \text { for Option } 5 . \mathrm{Ze}\end{array}$ & $\begin{array}{l}\text { labour cost fo } \\
\text { nal area of } 1.5 \\
\text { freeboard ass }\end{array}$ & $\begin{array}{l}\text { superstru } \\
{ }^{2} \text { for both } \\
\text { med for } 0\end{array}$ & $\begin{array}{l}\text { ture and s } \\
\text { ptions, an } \\
\text { tion } 6 \text {. }\end{array}$ & $\begin{array}{l}\text { tructure } \\
\text { nused pit }\end{array}$ \\
\hline Toilet type & $\begin{array}{l}\text { Minimum } \\
\text { volume of sub- } \\
\text { structure from } \\
\text { Eq. (1) }\left(\mathbf{m}^{3}\right)\end{array}$ & $\begin{array}{l}\text { Total } \\
\text { volume of } \\
\text { substruc- } \\
\text { ture }\left(\mathrm{m}^{3}\right)\end{array}$ & $\begin{array}{l}\text { Total depth } \\
\text { of sub- } \\
\text { structure } \\
\text { (m) }\end{array}$ & Cost $(€)$ \\
\hline VIP toilet with first $1.2 \mathrm{~m}$ of pit side walls being lined (for Option 5) & 4.2 & 5.1 & 3.4 & 348 \\
\hline Single vault UDD toilet (for Option 6) & 0.6 & 0.6 & 0.4 & 371 \\
\hline Comparison costs from others: & & & & \\
\hline VIP toilet in Uganda (Niwigaba et al., 2006) & & & & $106-211$ \\
\hline Double vault UDD toilet in Uganda (Niwigaba et al., 2006) & & & & $296-464$ \\
\hline Double vault UDD toilet in South Africa ${ }^{\mathrm{a}}$ & & & $\sim 0.5$ & 632 \\
\hline
\end{tabular}

a The municipality of eThekwini (Durban) in South Africa installed 37000 double vault UDD toilets in 2005 at this cost

(Gounden, 2006)

- Direct application of the faecal matter from the vaults in agricultural fields for restricted crops (such as fodder for animals or ornamental plants)

- Burial of the faecal matter in shallow pits on which fruit trees are planted.

The fertiliser produced from either option could be used in agriculture or in public gardens, parks, potted flowers or potted plants. It is likely that the solid fertiliser produced in Option 6 is of higher quality than the compost produced in Option 5 because the former is less contaminated with other substances and has a higher nitrogen content (no leaching of nitrogen into the ground). We used a conservative estimate for the sales price of compost or solid fertiliser in our calculations $(2 € / t)$. Others have reported approximately $28 € / \mathrm{t}$ for compost made from organic solid waste (Rothenberger et al., 2006) and $22 € / t$ for compost made from faecal sludge and organic solid waste (Vodounhessi and Von Münch, 2006).

The land required to absorb all nitrogen in the excreta is approximately 39000 ha for Option 6 (based on $5.7 \mathrm{~kg} \mathrm{~N}$ excreted/person a and an application rate of $180 \mathrm{~kg} \mathrm{~N} / \mathrm{ha} \cdot \mathrm{a}$ for maize (Jönsson et al., 2004)). Excreta collected from Option 5 could only fertilise a smaller area because nitrogen of the urine would seep into the ground at the location of the VIP latrine. The total area of Lusaka Province is 2200000 ha (CSO, 2003) and Lusaka City itself is approximately $36000 \mathrm{ha}$. Hence, the area of 39000 ha which would have to be set aside for (urban) agriculture represents about $2 \%$ of the total Lusaka Province area.

\section{Financial model for short-listed sanitation options}

Various authors have published cost estimates for sanitation systems (e.g. Hutton and Haller (2004), Rockström et al. (2005)) but the reported costs are often difficult to compare, e.g. because they only include Part A of the sanitation system, or only the first year of operation. A useful tool for a basic financial comparison of sanitation options is the Net Present Value (NPV) of the capital and annual operating costs of the entire sanitation system (Part A to E in Fig. 3). The option with the lowest absolute value for NPV is regarded as the most attractive option from a purely financial point of view.

We used a discount rate of $12 \%$ (equivalent to government borrowing rate) and a time period of 10 years in our NPV analysis; during this time-frame the options considered would not require replacements or major repairs. Where possible, we have formulated general cost equations for the financial model. The input parameters for the financial model (see Table 6) can be varied by the user of the model and should be verified for a specific application of the model.

The monetary benefits of Option 5 and 6 with respect to public health improvements are likely to be quite similar, and a cost-benefit analysis was therefore not carried out (the expected impacts on groundwater quality improvements for the two options are very difficult to assess in financial terms).

\section{Capital costs}

Capital costs for both options are summarised in Table 5, and the costs for Part A are explained in more detail below. The cost of a toilet increases with increasing volume of its 'substructure', i.e. the pit or vault. The minimum volume of the substructure is calculated by Eq. (1) below (parameter descriptions and values are provided in Table 6).

$$
\mathrm{V}_{\text {sub,min }}=\mathrm{p}_{\mathrm{f}} \cdot \mathrm{N}_{\mathrm{Lsk}} \cdot \mathrm{T}_{\mathrm{d}}
$$

The substructure volume of the toilets in Option 5 is much larger than the substructure volume of toilets in Option 6 because of the longer time period between desludging events assumed for Option 5, due to access restrictions for the vacuum tankers (see parameter $T_{d}$ in Table 6). The capital cost for one toilet of Part A of Option 5 (see Table 4) consists of pit excavation, pit lining (to $1.2 \mathrm{~m}$ depth), cover slab, superstructure and a vent pipe. For Option 6, the cost items for one UDD toilet are a floor slab, faeces vault, cover slab, superstructure, a vent pipe, $2 \times 200 \ell$ plastic barrels for urine storage, a urine-diversion squatting pan and a bucket for sand or ash. The cost of a simple superstructure is identical for the two options. Details of the cost estimates (bill of quantities) are provided in Mayumbelo (2006).

\section{Operating costs}

The equations used in the financial model to predict the operating costs of Part B, C and E ( $\left.\mathrm{C}_{\text {Part i, op }}\right)$ are shown below (symbol names, parameter values and units are provided in Table 6). The operating costs of both options are summarised in Table 8 .

$$
\begin{aligned}
& \mathrm{C}_{\text {Part B, op }}=\mathrm{F}_{\mathrm{d}} \cdot \mathrm{N}_{\mathrm{Lsk}} / \mathrm{N}_{\mathrm{P} / \mathrm{t}} \cdot \mathrm{C}_{\mathrm{ve}}+\left(\mathrm{F}_{\mathrm{w}, \mathrm{l}} \cdot \mathrm{p}_{\mathrm{f}}+\mathrm{p}_{\text {urine }}\right) \cdot \mathrm{N}_{\mathrm{Lsk}} \cdot \mathrm{C}_{\mathrm{t}, \mathrm{l}} / \mathrm{V}_{\mathrm{tv}} \\
& \mathrm{C}_{\text {Part C, op }}=\mathrm{F}_{\mathrm{w}, \mathrm{l}} \cdot \mathrm{p}_{\mathrm{f}} \cdot \mathrm{N}_{\mathrm{Lsk}} \cdot \mathrm{C}_{\mathrm{tr}, \mathrm{s}}+\mathrm{N}_{\mathrm{w}} \cdot \mathrm{C}_{\mathrm{w}, \mathrm{a}} \\
& \mathrm{C}_{\text {Part E, op }}=-\rho_{\text {comp }} \cdot \mathrm{F}_{\mathrm{w}, 2} \cdot \mathrm{F}_{\mathrm{w}, 1} \cdot \mathrm{p}_{\mathrm{f}} \cdot \mathrm{N}_{\mathrm{Lsk}} \cdot \mathrm{C}_{\text {comp }}-\mathrm{p}_{\text {urine }} \cdot \mathrm{N}_{\mathrm{Lsk}} \cdot \mathrm{C}_{\text {urine }}
\end{aligned}
$$




\begin{tabular}{|c|c|c|c|c|}
\hline \multicolumn{5}{|c|}{$\begin{array}{l}\text { TABLE } 5 \\
\begin{array}{l}\text { Capital costs for the short-listed sanitation options for Lusaka's peri-urban population of } 1.23 \mathrm{~m} . \\
\text { (in } € \text { unless otherwise indicated) - based on concept design in Table } 3\end{array}\end{array}$} \\
\hline \multicolumn{2}{|l|}{ Part } & $\begin{array}{c}\text { Option } 5 \\
\text { (VIP toilets }+ \\
\text { processing) }\end{array}$ & $\begin{array}{c}\text { Option } 6 \\
\text { (UDD toilets + } \\
\text { processing) }\end{array}$ & Comments \\
\hline Part A & $\begin{array}{l}\text { Toilets with sub- and super- } \\
\text { structure }\end{array}$ & 35650000 & 38010000 & Based on Table 4, for 102400 toilets \\
\hline Part B & $\begin{array}{l}\text { Trucks to transport the excreta } \\
\text { from toilets to treatment site }\end{array}$ & 1760000 & 1500000 & $\begin{array}{l}\text { Option 5: Cost of one new vacuum truck taken to be } \\
€ 110000 \\
\text { Option 6: Cost of one second-hand open truck: } € 50 \\
000 \text { (Vodounhessi and Von Münch, 2006) }\end{array}$ \\
\hline \multirow[t]{4}{*}{ Part C } & Faecal sludge treatment plant & 1309300 & 0 & $\begin{array}{l}\text { Based on a similar plant design for Kumasi, Ghana } \\
\text { (Vodounhessi and Von Münch, 2006); cost of land } \\
\text { not included }\end{array}$ \\
\hline & Dried faecal matter storage & 0 & 276000 & Mayumbelo (2006); cost of land not included \\
\hline & Urine storage tanks & 0 & 8109000 & Mayumbelo (2006) \\
\hline & Subtotal for Part C & 1309300 & 8385000 & \\
\hline Part D & $\begin{array}{l}\text { Trucks to transport the sani- } \\
\text { tised excreta }\end{array}$ & 0 & 0 & $\begin{array}{l}\text { Transport burden and urine storage costs shifted to } \\
\text { farmers }\end{array}$ \\
\hline Part E & $\begin{array}{l}\text { Sale of fertiliser / Ecosan } \\
\text { products }\end{array}$ & 0 & 0 & No capital cost item \\
\hline \multicolumn{2}{|c|}{ Total capital costs (million $€$ ) } & 39 & 48 & \\
\hline \multicolumn{2}{|c|}{ Total capital cost per capita (€/cap) } & 31 & 39 & \\
\hline
\end{tabular}

\begin{tabular}{|c|c|c|c|c|c|}
\hline \multicolumn{6}{|c|}{$\begin{array}{c}\text { TABLE } 6 \\
\text { Default input parameter values for financial model } \\
\text { (see Mayumbelo (2006) for further background information) }\end{array}$} \\
\hline Parameter & Symbol & Unit & $\begin{array}{l}\text { Option } 5 \\
\text { (VIP + } \\
\text { process- } \\
\text { ing) }\end{array}$ & $\begin{array}{l}\text { Option } 6 \\
\text { (UDD + } \\
\text { process- } \\
\text { ing) }\end{array}$ & Further explanations \\
\hline $\begin{array}{l}\text { Sales prices of compost or dried faecal } \\
\text { matter }\end{array}$ & $\mathrm{C}_{\text {comp }}$ & $€ / \mathrm{t}$ & 2 & 2 & Current price for biosolids from WWTP in Lusaka \\
\hline $\begin{array}{l}\text { Cost of using a transport vehicle for trans- } \\
\text { port from plot to treatment site }\end{array}$ & $\mathrm{C}_{\mathrm{t}, 1}$ & $€ /$ event & 72 & 60 & $\begin{array}{l}\text { Independent of travel distance (current practice in } \\
\text { Lusaka); includes pit emptying for Option } 5\end{array}$ \\
\hline Cost of treating faecal sludge & $\mathrm{C}_{\mathrm{tr}, \mathrm{s}}$ & $€ / \mathrm{m}^{3}$ & 2.4 & 0 & Based on current charge of LWSC for Option 5 \\
\hline Sales price for urine & $\mathrm{C}_{\text {urine }}$ & $€ / \mathrm{m}^{3}$ & 0 & 0.75 & $\begin{array}{l}\text { Nutrients worth } € 0.15 \text { per } 20 \ell \text { jerry can (Dagerskog, } \\
2006 \text { ); used } 10 \% \text { of this 'theoretical value' here. }\end{array}$ \\
\hline Cost of vault emptying, per event & $\mathrm{C}_{\mathrm{ve}}$ & $€ /$ event & 0 & 5 & Assuming $30 \mathrm{~min}$, and $10 € / \mathrm{h}$ salary cost \\
\hline Annual cost of a general worker & $\mathrm{C}_{\mathrm{w}, \mathrm{a}}$ & $€ / \mathrm{a}$ & 0 & 4300 & Typical salary for a general worker in Lusaka for Option 6 \\
\hline Frequency of desludging or emptying & $\mathrm{F}_{\mathrm{d}}$ & $1 / \mathrm{a}$ & 0.2 & 1 & $=1 / \mathrm{T}_{\mathrm{d}}$ \\
\hline $\begin{array}{l}\text { Factor to account for volume change in } \\
\text { Part B }\end{array}$ & $\mathrm{F}_{\mathrm{w}, 1}$ & - & 2 & $0.5^{\mathrm{a}}$ & Option 5: Increase due to necessary water jetting \\
\hline $\begin{array}{l}\text { Factor to account for water loss during } \\
\text { treatment in Part C }\end{array}$ & $\mathrm{F}_{\mathrm{w}, 2}$ & - & 0.1 & 0.5 & $\begin{array}{l}\text { For Option 5: Compost yield from faecal sludge is about } \\
0.1 \mathrm{t} / \mathrm{m}^{3} \text { (Vodounhessi and Von Münch, 2006). Option 6: } \\
\text { some further drying will occur (total: } \mathrm{F}_{\mathrm{w}, 1} \times \mathrm{F}_{\mathrm{w}, 2}=0.25 \text { ) }\end{array}$ \\
\hline Number of households per plot & $\mathrm{N}_{\mathrm{hh} / \mathrm{pl}}$ & - & 3 & 3 & See Table 1 \\
\hline Number of people covered in the scheme & $\mathrm{N}_{\text {Lsk }}$ & Cap & \multicolumn{2}{|c|}{1229323} & Design value (peri-urban population) \\
\hline Number of people per household & $\mathrm{N}_{\mathrm{p} / \mathrm{hh}}$ & - & 4 & 4 & Own estimate \\
\hline Number of people per toilet & $\mathrm{N}_{\mathrm{P} / \mathrm{t}}$ & - & 12 & 12 & $=\mathrm{N}_{\mathrm{hh} / \mathrm{pl}} \times \mathrm{N}_{\mathrm{p} / \mathrm{hh}}$ \\
\hline Number of workers at the storage site & $\mathrm{N}_{\mathrm{w}}$ & - & 0 & 5 & Design value \\
\hline $\begin{array}{l}\text { Specific annual faecal sludge or faeces } \\
\text { production }\end{array}$ & $\mathrm{p}_{\mathrm{f}}$ & $\mathrm{m}^{3} / \mathrm{cap} \cdot \mathrm{a}$ & 0.07 & 0.05 & $\begin{array}{l}\text { Heinss et al. (1998) for Option 5; Jönsson et al. (2004) for } \\
\text { Option } 6 \text { (faeces production at point of excretion) }\end{array}$ \\
\hline Specific annual urine production & $\mathrm{p}_{\text {urine }}$ & $\mathrm{m}^{3} /$ cap·a & 0 & 0.5 & $=500 \ell /$ cap $\cdot$ a or $1.37 \ell /$ cap·d (Jönsson et al., 2004) \\
\hline Density of compost or dried faecal matter & $\rho_{\text {comp }}$ & $\mathrm{t} / \mathrm{m}^{3}$ & 1.2 & 1.2 & Own estimate \\
\hline $\begin{array}{l}\text { Time between desludging or emptying } \\
\text { events }\end{array}$ & $\mathrm{T}_{\mathrm{d}}$ & years & 5 & 1 & Own design value \\
\hline $\begin{array}{l}\text { Volume of substructure (without free- } \\
\text { board) }\end{array}$ & $\mathrm{V}_{\text {sub,min }}$ & $\mathrm{m}^{3}$ & 4.2 & 0.6 & Equals sludge volume when pit or vault is full \\
\hline Volume of transport vehicle & $\mathrm{V}_{\mathrm{tv}}$ & $\mathrm{m}^{3}$ & 5 & 15 & Vacuum tanker in Option 5, skip on open truck in Option 6 \\
\hline
\end{tabular}

${ }^{a}$ Conservative estimate since fresh faeces at excretion are about $80 \%$ water (Jönsson et al., 2004);

total volume reduction factor could be as low as 0.2 . 


\begin{tabular}{|l|l|c|c|c|}
\hline \multirow{4}{*}{$\begin{array}{c}\text { Quantities of excreta to be moved (based on } \mathbf{1 . 2 3} \text { m. people and calculated using adapted Eq. (2) for } \\
\left.\text { Part B and adapted Eq. (4) for Part D). Density of material in Part D as shown in Table 6 ( } \rho_{\text {comp }}\right) \text { ) }\end{array}$} \\
\hline \multirow{2}{*}{ Transport step } & Quantity parameter & $\begin{array}{c}\text { Option 5 } \\
\text { (VIP + processing) }\end{array}$ & \multicolumn{2}{c|}{$\begin{array}{c}\text { Option 6 } \\
\end{array}$} \\
& & Faecal sludge & Faecal matter & Urine \\
\cline { 2 - 4 } & & 172100 & 30700 & 614700 \\
\hline Part B & Volume $\left(\mathrm{m}^{3} / \mathrm{a}\right)$ & 17200 & 15400 & 614700 \\
\hline Part D & Volume $\left(\mathrm{m}^{3} / \mathrm{a}\right)$ & 20600 & 18500 & 614700 \\
\cline { 2 - 5 } & Mass (t/a) & &
\end{tabular}

a Assuming that there are no evaporation losses and specific gravity of urine is 1.0

\begin{tabular}{|c|c|c|c|c|}
\hline \multicolumn{5}{|c|}{$\begin{array}{c}\text { TABLE } 8 \\
\begin{array}{c}\text { Operating costs for the short-listed sanitation options for Lusaka's peri-urban population of } 1.23 \mathrm{~m} . \\
\text { (in } € / \text { a unless otherwise indicated) - based on concept design in Table } 3\end{array}\end{array}$} \\
\hline \multicolumn{2}{|c|}{ Part } & \begin{tabular}{|c|} 
Option 5 \\
(VIP toilets + \\
processing)
\end{tabular} & $\begin{array}{l}\text { Option } 6 \\
\text { (UDD toilets }+ \\
\text { processing) }\end{array}$ & Comments \\
\hline Part A & Operation and maintenance costs for toilets & 0 & 0 & $\begin{array}{l}\text { Robust structures requiring only cleaning; } \\
\text { cost of additive for Option } 6 \text { negligible }\end{array}$ \\
\hline \multirow[t]{4}{*}{ Part B } & Cost of removing faecal matter from vault & 0 & 512000 & $\begin{array}{l}\text { Option 5: included in next line item } \\
\text { Option 6: first part of Eq. (2) }\end{array}$ \\
\hline & $\begin{array}{l}\text { Faecal sludge / faecal matter transport from } \\
\text { plot to treatment plant / storage site }\end{array}$ & 2478000 & 123000 & Second part of Eq. (2) \\
\hline & $\begin{array}{l}\text { Transport of urine barrels from plot to } \\
\text { storage site }\end{array}$ & 0 & 2459000 & Third part of Eq. (2) \\
\hline & Subtotal for Part B & 2478000 & 3094000 & \\
\hline \multirow[t]{3}{*}{ Part C } & Treatment costs & 413000 & 0 & First part of Eq. (3) \\
\hline & Staff labour at storage site & 0 & 21000 & Second part of Eq. (3) \\
\hline & Subtotal for Part C & 413000 & 21000 & \\
\hline Part D & Transport cost of sanitised excreta to user & 0 & 0 & Transport costs to be covered by farmers \\
\hline \multirow[t]{3}{*}{ Part E } & $\begin{array}{l}\text { Income from sale of treated sludge or faecal } \\
\text { matter }\end{array}$ & -41000 & -37000 & $\begin{array}{l}\text { First part of Eq. (4) (note negative value } \\
\text { since it is an income) }\end{array}$ \\
\hline & Income from sale of urine & 0 & -461000 & Second part of Eq. (4) \\
\hline & Subtotal for Part E & -41000 & -498000 & \\
\hline \multicolumn{2}{|c|}{ Total operating costs (million $€ / \mathrm{a})$} & 2.9 & 2.6 & \\
\hline \multicolumn{2}{|c|}{ Total operating costs per capita (€/cap·a) } & 2.3 & 2.1 & \\
\hline
\end{tabular}

TABLE 9

Output parameter values from financial model for Lusaka's entire peri-urban population (1.23 m. people) (the lower the absolute value of NPV, the better)

\begin{tabular}{|l|c|c|}
\hline Model output parameter & $\begin{array}{c}\text { Option 5 } \\
\text { (VIP toilets + processing) } \mathbf{6}\end{array}$ & $\begin{array}{c}\text { OpD toilets + processing) } \\
\text { (UD }\end{array}$ \\
\hline Total capital costs (million $€$ ) & 39 & 48 \\
\hline Capital costs per capita $(€ /$ cap) & 31 & 2.6 \\
\hline Total operating costs (million €/a) & 2.9 & 2.1 \\
\hline Operating costs per capita (€/a-cap) & 2.3 & 63 \\
\hline $\begin{array}{l}\text { NPV (million } € \text { ), based on 12\% discount rate and 10 years project } \\
\text { lifetime }\end{array}$ & 55 & \\
\hline
\end{tabular}

The default model parameter values shown in Table 6 are the result of a simplistic analysis, which does not take into account the fact that the residents will spend part of their day outside the peri-urban areas, the lower excreta production rates of children, nor the weight of the material added after defecation to cover the material and absorb moisture. The quantities of excreta to be moved in the two transport steps (Part B and Part D) are shown in Table 7. A summary of the financial model output values is provided in Table 9.

\section{Discussion of cost estimates}

The following observations can be made regarding the capital costs:

- The accuracy of the cost estimate is expected to be $\pm 25 \%$ for a concept design of this nature. Hence, whilst the capital cost and NPV are higher for Option 6 than for Option 5, this difference is not significant compared to the accuracy of the estimate. 
- Part A (toilets) constitutes by far the largest contribution to the overall capital costs for both options. Hence the biggest potential for capital cost savings lies in Part A.

- The second biggest contributor to the costs of Option 6 is the urine storage facility. Urine storage has two purposes: hygienisation (e.g. to reduce those pathogens that stem from cross-contamination with faeces); and storage (i.e. storing urine while it is not needed by the farmers). Longer urine storage times reduce health risks but also increase capital costs. We used two weeks as a minimum time needed to buffer farmers' demand but clearly, the practicalities of this assumption need further consideration.

The following observations can be made regarding the operating costs:

- The operating costs are slightly lower for Option 6 than for Option 5, but the difference is not significant within the accuracy of the estimate

- The largest contribution to the operating costs originates from Part B (excreta collection and transportation to treatment plant) for both options. The high transport costs of the urine barrels are a potential barrier to the adoption of Option 6. Transport in small-bore pipes, together with greywater, could be an alternative option in some cases but may be more capital cost intensive.

- The sale of urine has potential to generate a significant income due to its nitrogen and phosphorus content whilst being virtually pathogen-free. The achievable sales price for urine requires further investigations (a conservative sales price was used here).

The NPV values of both options are close to each other (the NPV of Option 6 is only 14\% higher than the NPV for Option 5). In summary, we can conclude that in the case of Lusaka, the Ecosan option (Option 6) cannot be ruled out based on cost, compared to the conventional VIP latrine-based option (Option 5).

\section{Conclusions}

Because Ecosan is still a relatively new and little-known approach to sanitation, many municipalities do not realise that it could be a viable and cost-effective alternative to sewer-based sanitation systems, septic tanks or pit latrines. Decision makers need adequate information regarding the costs of the entire sanitation system. Many previous publications that dealt with costs of sanitation only provided the capital costs of the toilet without the accompanying downstream processing infrastructure and annual operating costs.

We have developed basic equations to calculate:

- The minimum volume of the toilet's substructure; this has an impact on the capital cost of Part A (toilets);

- Operating costs of Part B (transport), Part C (treatment/storage) and Part E (sale of fertiliser)

The equations use a set of input parameters for which default values suitable for conditions similar to Lusaka are provided (we used $1.23 \mathrm{~m}$. people living in peri-urban areas as a design basis). The capital cost and NPV for Option 6 (UDD toilets with processing) were found to be higher than for Option 5 (VIP toilets with processing), whilst the annual operating cost of Option 6 was slightly lower (but the difference was less than the expected accuracy of $\pm 25 \%$ for a concept design of this nature). The costs presented in this paper are of an indicative nature and serve to illustrate our cost comparison methodology. Further work is needed to refine the detailed design of the options as well as the values of the model input parameters, which will also vary from country to country.

In order to contribute to public health improvements in periurban areas, it is necessary to have a sanitation system that is sustainable in all aspects, i.e. socially, technically, environmentally, institutionally and financially. This paper focuses on the financial aspects of sanitation systems. Financial sustainability is only one aspect in the decision making process amongst many others (e.g. user acceptance, cultural factors, institutional capacity to name but a few). One conclusion that can be drawn from our analysis of the entire sanitation system, is that the proposed Ecosan option is cost competitive compared to the commonly used option of VIP latrines with downstream processing - with the Ecosan option having the added benefit of a lower potential for groundwater pollution via leaching of nitrate and pathogens from stored excreta.

\section{Acknowledgements}

We thank the Dutch government for granting an M.Sc. fellowship to Mr. Mayumbelo, as part of its MDG-related 'Watermill' project. We also thank Mr. G de Bruijne from WASTE Urban Advisers (Gouda, the Netherlands) for providing valuable ideas and suggestions for this work.

\section{References}

CARDEN K, ARMITAGE N, WINTER K, SICHONE O and RIVETT U (2007) Understanding the Use and Disposal of Greywater in the Non-Sewered areas of South Africa. WRC Report No. 1524/1/07. Water Research Commission, Pretoria, South Africa. http:// www.wrc.org.za/downloads/report $\% 20$ lists/web $\% 20 \mathrm{rpts} / \mathrm{munic} /$ Full1524 1 07.pdf (Accessed on 28 June 2007)

CSO (2003) 2000 Census of population and housing, Central Statistics Office, Lusaka, Zambia. www.zamstats.gov.zm/dload/cen.asp (Accessed on 27 June 2007)

DAGERSKOG L (2006) Personal communication. CREPA, Ouagadougou, Burkina Faso.

DRANGERT JO (1998) Fighting the urine blindness to provide more sanitation options. Water SA 24 (2)157-164. www.wrc.org.za/ archives/watersa\%20archive/1998/April/apr98 p157.pdf (Accessed on 26 June 2007).

GKW (2005) Baseline Study on Water Supply and Sanitation for PeriUrban and Low Cost Areas in Zambia. National Water and Sanitation Council \& Devolution Trust Fund, Lusaka, Zambia (available: water4all@dtf.org.zm).

GTZ (2007) Technical Data Sheets for Ecosan Components. GTZ. (Online) http://www.gtz.de/en/themen/umwelt-infrastruktur/wasser /9397.htm (Accessed on 28 June 2007).

GOUNDEN T (2006) Personal communication. Manager Community Education, e-Thekwini Water and Sanitation, Durban, South Africa).

GUNESS M, PILLAY S, RODDA N, SMITH M, BUCKLEY C and MACLEOD N (2006) Quality of leachate from buried urine diversion toilet waste. Proc. Water Institute of South Africa Conference. 22-25 May 2006, Durban, South Africa.. www.ewisa.co.za/frame.aspx?url= / literature/default.aspx \&cat=8 (Accessed on 28 June 2007).

HEINSS U, LARMIE SA and STRAUSS M (1998) Solids Separation and Pond Systems for the Treatment of Faecal Sludges in the Tropics. Lessons Learnt and Recommendations for Preliminary Design. Sandec Report No. 05/98, Eawag/Sandec, Dübendorf, Switzerland. www.eawag.ch/organisation/abteilungen/sandec/publikationen/publications ewm/ewm ponds (Accessed on 28 June 2007).

HUTTON G and HALLER L (2004) Evaluation of the Costs and Benefits of Water and Sanitation Improvements at the Global Level. WHO, Geneva, Switzerland. whqlibdoc.who.int/hq/2004/WHO SDE_WSH_04.04.pdf (Accessed on 27 June 2007). 
JÖNSSON H, RICHERT STINTZING A, VINNERAS B and SALOMON E (2004) Guidelines on Use of Urine and Faeces in Crop Production. Report 2004-2, Stockholm Environment Institute, Stockholm, Sweden. www.ecosanres.org/pdf files/ESR Publications 2004/ESR2web.pdf (Accessed on 27 June 2007).

KVARNSTRÖM E and AF PETERSENS E (2004) Open Planning of Sanitation Systems Report No. 2004-3. Stockholm Environment Institute, Stockholm, Sweden. www.ecosanres.org/pdf files/ESR Publications 2004/ESR3web.pdf (Accessed on 27 June 2007).

LERNER DN (2004) Urban Groundwater Pollution. AA Balkema Publishers, Lisse, the Netherlands.

MAYUMBELO KMK (2006) Cost Analysis for Applying Ecosan in Peri-Urban Areas to Achieve the MDGs - Case study of Lusaka, Zambia. M.Sc. Thesis MWI 2006-10, UNESCO-IHE, Delft, the Netherlands. www2.gtz.de/Dokumente/oe44/ecosan/en-cost-analysis-lusaka-2006.pdf (Accessed on 27 June 2007).

MILLENNIUM-PROJECT (2005) Investing in Development, a Practical Plan to Achieve the Millennium Development Goals. Overview. United Nations Millennium Project, Washington D.C. www. unmillenniumproject.org/documents/overviewEngLowRes.pdf (Accessed on 27 June 2007).

MOILWA N and WILKINSON M (2006) The effect of hygiene communication on emptying of urine diversion toilets. Proc. $32^{\text {nd }}$ WEDC International Conference. November 2006, Colombo, Sri Lanka.. wedc.lboro.ac.uk/conferences/pdfs/32/Moilwa.pdf (Accessed on 27 June 2007)

NIWIGABA BC, KINOBE JR, ATWINE E and KISAKA JN (2006) Towards a sanitation selection algorithm for enhancing decentralized service delivery. Proc. $32^{\text {nd }}$ WEDC International Conference. November 2006, Colombo, Sri Lanka. wedc.lboro.ac.uk/conferences/pdfs/32/Niwagaba.pdf (Accessed on 27 June 2007).

NKUWA DCW (2002) Human activities and threats of chronic epidemics in a fragile geologic environment. Proc. $3^{\text {rd }}$ WaterNet/Warfsa Symposium 'Water Demand Management for Sustainable Development'. 30-31 October 2002, Dar es Salaam, Tanzania. http://www. waternetonline.ihe.nl/aboutWN/pdf/Nkhuwa.pdf (Accessed on 27 June 2007).

ROCKSTRÖM J, AXBERG GN, FALKENMARK M, LANNERSTAD
M, ROSEMARIN A, CALDWELL I, ARVIDSON A and NORDSTRÖM M (2005) Sustainable Pathways to Attain the Millennium Development Goals: Assessing the Key Role of Water, Energy and Sanitation. Stockholm Environment Institute, Stockholm, Sweden. www.ecosanres.org/pdf_files/MDGRep/SustMDG31Auglowres. pdf (Accessed on 27 June 2007).

ROSEMARIN A (2003) Putting Ecosan on the global agenda - results from the $3^{\text {rd }}$ World Water Forum, Kyoto, March 16-23, 2003. Proc. $2^{\text {nd }}$ Int. Symp. on Ecological Sanitation. April, 2003, Lübeck, Germany. www.gtz.de/ecosan/download/ecosan-Symposium-Luebeckopening-session.pdf (Accessed on 27 June 2007).

ROTHENBERGER S, ZURBRÜGG C, ENAYETULLAH I and MAQSOOD SINHA AHM (2006) Decentralised Composting for Cities of Low- and Middle-Income Countries - A Users' Manual. Eawag/ Sandec (Switzerland) and Waste Concern (Bangladesh), Dübendorf, Switzerland. www.eawag.ch/organisation/abteilungen/sandec/publikationen/publications swm/downloads swm/decomp_Handbook loRes.pdf (Accessed on 27 June 2007).

UNEP (2004) Financing wastewater collection and treatment in relation to the Millennium Development Goals and World Summit on Sustainable Development targets on water and sanitation, United Nations Environment Programme (UNEP), Jeju, Republic of Korea. www.unep.org/GC/GCSS-VIII/K0470227\%20INF4.pdf (Accessed on 27 June 2007).

VODOUNHESSI A and VON MÜNCH E (2006) Financial and institutional challenges to make faecal sludge management integrated part of Ecosan approach: Case study of Kumasi, Ghana. Water Practice and Technology, 1(2).www.iwaponline.com/wpt/001/0045/0010045. pdf (Accessed on 27 June 2007).

VON MÜNCH E, AMY G and FESSELET J-F (2006) The potential of Ecosan to provide sustainable sanitation in emergency situations and to achieve quick wins in MDGs. Water Practice and Technology, 1 (2). www.iwaponline.com/wpt/001/0037/0010037.pdf (Accessed on 27 June 2007).

WINBLAD U and SIMPSON-HÉBERT M (2004) Ecological Sanitation (revised and enlarged edition). Stockholm Environment Institute, Stockholm, Sweden ( $2^{\text {nd }}$ edn.). www.ecosanres.org/ES2 download. htm (Accessed on 27 June 2007). 